Jurnal Health Sains: p-ISSN: 2723-4339 e-ISSN: 2548-1398

Vol. 2, No. 3, Maret 2021

\title{
INFEKSI PARASIT, HUBUNGANNYA DENGAN KARSINOGENESIS
}

\section{Selfi Renita Rusjdi}

Fakultas Kedokteran Universitas Andalas, Padang, Sumatera Barat, Indonesia

Email: selfirenitarusjdi@med.unand.ac.id

\begin{tabular}{l}
\hline ARTIKEL INFO \\
\hline Tanggal diterima: 5 Maret 2021 \\
Tanggal direvisi: 15 Maret 2021 \\
Tanggal disetujui: 25 Maret \\
2021
\end{tabular}

Keywords:

parasitic infection; malignancy; carsinogen

\begin{abstract}
Malignancy diseases can occur due to the influence of environmental and physiological conditions. Several epidemiological studies and case reports have shown that there is a link between parasitic infection and carcinogenesis. There are several organisms that belong to parasites that are very closely related to malignant diseases, among others; Schistosoma sp, Strongyloides stercoralis, Plasmodium sp, Chlonorchis sinensis, Opistorchis viverrini, Trypanosoma cruzi. These organisms hijack celluler pathways to manipulate the epigenome of host cells, organelles, signaling pathways and epigenetic programs. Literature search was conducted by qualitative method in November 2020-January 2021 using secondary data. The purpose of this writing is to find out Parasitic Infections, Their Relationship With Carcinogenesis. This paper discusses the epidemiology and mechanisms of parasitic infection inducing the occurrence of malignancy diseases (carcinogenesis). The conclusion of this writing is that the relationship between parasite infection and carcinogenesis has been widely proven. Schistosoma haematobium, Opistorchis viverrini and Chlonorchis sinensis have higher carcinogeic potential than Opistorchis felineus and Schistosoma.
\end{abstract}

\section{ABSTRAK}

Penyakit keganasan dapat terjadi karena pengaruh kondisi lingkungan dan fisiologi. Beberapa studi epidemiologi dan laporan kasus memperlihatkan bahwa terdapatnya hubungan antara infeksi parasit dengan karsinogenesis. Terdapat beberapa organisme yang tergolong ke dalam parasit yang sangat erat kaitannya dengan penyakit keganasan antara lain; Schistosoma sp, Strongyloides stercoralis, Plasmodium sp, Chlonorchis sinensis, Opistorchis viverrini, Trypanosoma cruzi. Organisme ini membajak celluler pathways untuk memanipulasi epigenom sel host, organel, signaling pathway dan program epigenetik. Pencarian literatur dilakukan dengan metode kualitatif pada bulan November 2020-Januari 2021 dengan menggunakan data sekunder. Tujuan penulisan ini adalah untuk mengetahui Infeksi Parasit, Hubungannya Dengan Karsinogenesis. Tulisan ini membahas tentang epidemiologi dan mekanisme infeksi parasit menginduksi 
Kata Kunci:

infeksi parasit; keganasan; karsinogen terjadinya penyakit keganasan (karsinogenesis). Kesimpulan dari penulisan ini adalah hubungan antara infeksi parasite dengan karsinogenesis telah banyak dibuktikan. Schistosoma haematobium, Opistorchis viverrini dan Chlonorchis sinensis mempunyai potensi karsinogeik yang lebih tinggi dibandingkan Opistorchis felineus dan Schistosoma.
Coresponden Author:

Email: selfirenitarusjdi@med.unand.ac.id Artikel dengan akses terbuka dibawah lisensi

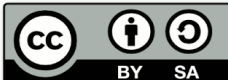

\section{Pendahuluan}

Munculnya penyakit keganasan diketahui dengan melihat adanya pertumbuhan sel yang abnormal dan tidak terkendali. Diperkirakan bahwa terdapat sekitar 14,1 juta kasus baru penyakit keganasan di dunia dan sekitar 8,2 juta kasus berakhir dengan kematian (Organization, 2013). Keganasan tersebut antara lain menyerang esofagus, paru, hati, organ intra abdomen dan kolorektal. Semua penyakit keganasan tersebut di atas berhubungan dengan kejadian infeksi parasite yang berbeda-beda. Pada beberapa penelitian melaporkan bahwa trematoda hati; Opistorchis viverrini, Clonorchis sinensis dapat menyebabkan terjadinya kolangiokarsinoma dan treamatoda darah; Schistosoma haematobium erat kaitannya dengan kejadian keganasan pada vesica urinaria (Bouvard et al., 2009). Infeksi Plasmodium $S p$ yang terjadi bersama dengan infeksi virus Epstein Barr sangat erat hubungan dengan kejadian limfoma Burkitt (Molyneux et al., 2012). Trypanosoma cruzi yang dikenal sebagai penyebab penyakit Chagas bahkan pernah dilaporkan mempunyai peranan dalam karsinogenesis maupun sebagai anti kanker (Krementsov et al., 2019).

\section{Metode Penelitian}

Pencarian literatur dilakukan dengan metode kualitatif pada bulan November 2020-
Januari 2021 dengan menggunakan data sekunder. Perumusan pertanyaan penelitian menggunakan PICOS (Population/Problem, interest/Intervention, Comparison, Outcome dan Study design) dan menggunakan kata kunci yang disesuaikan dengan Medical Subject Heading (MeSH) yaitu Parasitic Infection OR Malignancy OR Carcinogen OR Carcinogenesis. Pencarian artikel didapatkan dari database Scopus, Sciencedirect, Lancet dan Parasitology menggunakan kata kunci yang dipilih dan dengan artikel berbahasa inggris, dapat diakses secara fulltext dan open access.

\section{Hasil Penelitian dan Pembahasan}

\section{A. Hasil Penelitian}

Penelusuran artikel didapatkan bahwa terdapat beberapa parasit yang menginfeksi manusia yang dapat menimbulkan perubahan ke arah keganasan pada host yang ditempatinya.

1. Shistosomiasis dan Keganasan
Schistosomiasis merupakan
penyakit yang disebabkan oleh trematoda darah yaitu Schistosoma sp. Angka kejadian schistosmiasis di seluruh dunia diperkirakan lebih dari 207 juta kasus. Terdapat lima spesies yang dapat menginfeksi manusia, yaitu; Schistosoma haematobium, $S$. mansoni, $S . \quad$ japonicum, $S$. intercalatum, dan $S . \quad$ mekongi. 
Beberapa faktor yang mempengaruhi kejadian

schistosomiasis adalah; resiko terpapar dengan stadium infektif, keberadaan siput sebagai hospes intermediet, keadaan hygiene dan sanitasi serta faktor genetik. Induksi karsinogenesis terjadi apabila terdapat interaksi antara host dengan parasit maupun antara host dengan produk parasite (Brindley et al., 2015).

The International Agency For Research On Cancer (IARC) menyatakan bahwa Schistosoma haematobium merupakan penyebab squamous cell carsinoma pada keganasan vesica urinaria dan dikelompokkan menjadi karsinogen grup I (Humans, 2012). Kesimpulan ini dibuat berdasarkan hasil analisa statistik yang menyatakan hubungan postif yang kuat dari berbagai macam kasus dan beberapa penelitian kasus kontrol. Sebagai contoh sebuah artikel review di Afrika mendapatkan sebanyak 217 kasus keganasan vesica urinarisa dalam 5 tahun periode di mana sebagian besar kasus merupakan well- differentiated squamous cell carcinoma (75\%). Pada suatu studi retrospektif yang dilakukan pada 184 spesimen biopsi dari keganasan primer vesica urinaria ditemukan sekitar 40,8\% kasus schistosomiasis. Penelitian yang dilakukan di Tanzania Utara pada 172 kasus keganasan kandung kencing ditemukan 72\% squamous cell carcinoma dengan $46 \%$ di antaranya ditemukan telur Schistosoma haematobium pada jaringan tumor. Beberapa laporan kasus juga pernah melaporkan bahwa schistosomiasis haematobium juga berhubungan dengan kejadian squamous cell carcinoma pada cervix dan adenocarsinoma prostat (Emilio Sánchez-Moyano et al., 2017).

Pada beberapa penelitian dilaporkan bahwa Schistosoma japonicum berhubungan dengan kejadian keganasan pada hati dan kolorektal. Penelitian yang dilakukan di Jepang didapatkan sebanyak 19,1\% (173/907) pasien penyakit hati kronik dan $\quad 51 \% \quad(35 / 68) \quad$ keganasan hepatoseluler terinfeksi oleh Schistosoma japonicum. Analisa data yang dilakukan dari 571 kasus autopsi keganasan hati dan penyakit kronik hati lainnya juga menunjukkan hasil yang sama. Penelitian eksperimental menunjukkan bahwa keganasan hepar dapat muncul lebih awal pada hewan yang diinduksi bahan karsinogen yang diinfeksi dengan Schistosoma japonicum dalam jumlah yang banyak (Emilio Sánchez-Moyano et al., 2017).

Beberapa studi literatur diketahui bahwa infeksi Schistosoma mansoni mempunyai hubungan yang tidak langsung dengan keganasan hepatoseluler. Pasien yang terinfeksi Schistosoma mansoni mempunyai prevalensi infeksi virus Hepatitis B dan Hepatitis C yang tinggi. Studi lain menujukkan bahwa pasien yang terinfeksi Schistosoma mansoni akan mengalami penekanan cell mediated immune response. Cacing Schistosoma mempengaruhi response imun dengan 2 cara, sehingga akan berakibat terhadap kelangsungan infeksi virus pada penderita. Cara tersebut adalah; 1) penderita schistosomiasis akan membentuk antiidiotype antibody sehingga akan menekan respon imun spesifik dan non spesifik, 2) Antigen yang berasal dari telur Schistosoma mansoni dapat memodifikasi sel Thelper menjadi polarized Th2 yang 
bersifat menekan Thelper1. Schistosomal colitis berhubungan dengan kemunculan kanker kolorektal yang lebih awal, tingginya kejadian muscinous cell carcinoma dan progresifitas keganasan. Studi lain juga menyimpulkan bahwa schistosomal colitis menyebabkan perubahan aktivasi P53 yang dapat memicu perkembangan keganasan kolorektal (Emilio Sánchez-Moyano et al., 2007).

2. Infeksi Trematoda hati dan Keganasan

Opistorchiasis dan clonorchiasis merupakan penyakit yang disebabkan oleh trematoda hati yang penularannya terjadi dengan cara tertelan metaserkaria yang terdapat pada kulit atau daging ikan yang tidak dimasak dengan matang. Diperkirakan lebih dari 45 juta penduduk di dunia terinfeksi oleh cacing ini. Beberapa spesies yang dapat menginfeksi manusia antara lain; Opisthorchis felineus, Opisthorchis viverrini, and Clonorchis sinensis (Tong et al., 2017).

The International Agency For Research On Cancer (IARC) mengklasifikasikan Clonorchis sinensis sebagai karsinogen grup I. Opistorchis felineus merupakan penyebab infeksi cacing endemik di Eropa dan Asia; Clonorchis sinensis di China, Korea dan Vietnam Utara; Opistorchis viverrini di Asia Tenggara (Petney et al., 2013). Opistorchis dan Chlonorchis juga sangat endemik di Laos, Thailand, Kamboja dan Vietnam (Sithithaworn et al., 2012). Peningkatan kejadian infeksi disebabkan oleh kebiasaan memakan ikan mentah yang mengandung metaserkaria. Keadaan patologi yang disebabkan cacing ini dapat berupa fibrosis duktus biliaris, cholangitis, ikterus obstruksi, hepatomegali, nyeri abdomen dan mual. Metaserkaria yang masuk ke saluran cerna akan mengalami ekskistasi di duodenum, bermigrasi ke ductus biliaris dan cacing dewasa akan mengambil makanan dari epitel bilier dan cairan empedu yang nantinya akan mengakibatkan hiperplasia epitel dan fibrosis (Tong et al., 2017).

Cholangiokarsinoma atau keganasan pada saluran empedu merupakan keganasan yang agresif dan mempunyai prognosa yang buruk. Kejadian cholangiokarsinoma berkisar $20 \%$ dari seluruh keganasan hepatobilier dan dapat terjadi intrahepatik dan ekstrahepatik. Morbiditas dan mortalitas cenderung untuk terus meningkat. Hal ini disebabkan karena masih belum ditemukannya terapi yang efektif. Faktor resiko mayor yang ikut berperan terhadap kejadian cholangiokarsinoma ini adalah genetik, lingkungan, penyakit hati lainnya yang ikut menyertai, penyakit infeksi kronik termasuk penyakit infeksi parasit ini (Palmer, 2012). Hubungan cholangiokarsinoma dengan infeksi Opistorchis dan Chlonorchis telah dibuktikan oleh penelitian eksperimental, epimiologi dan data dari laporan kasus. Hipotesis mengenai mekanisme efek karsinogenesis dari infeksi cacing ini antara lain; kerusakan epitel saluran empedu oleh parasit, imunopatogenesis akibat infeksi parasit, pengaruh antigen / produk yang dihasilkan parasit terhadap saluran empedu dan modifikasi terhadap proliferasi sel host (Brindley et al., 2015)

Hubungan antara infeksi Chlonorchis sinensis dengan cholangiokarsinoma telah banyak 
dilaporkan tetapi mekanisme penyebabnya masih belum dapat dipastikan. Cacing dewasa Chlonorchis sinensis dapat bermuara di saluran pancreas sehingga memicu terjadinya metaplasia epitel, hiperplasia mukosa kelenjar dan well differentiated adenocarcinoma pada saluran pankreas. Infeksi C.sinensis menyebabkan terjadinya hubungan yang terbalik antara ekspresi peroxiredoxin $6 \quad(\operatorname{Prdx} 6)$ dengan aktivasi NF-kB. Hal ini terjadi akibat pengaruh produk eksresi maupun sekresi cacing (Park \& Park, 2016). C.sinensis juga dapat menginduksi ekspresi berbagai produk peroksidasi lipid. Kejadian ini membuktikan bahwa Chlonorchiasis juga menyebabkan stress oksidatif yang dapat mengakibat berbagai kerusakan jaringan (Maeng et al., 2016).

Hubungan infeksi Opistorchis felineus dengan cholangiokarsinoma juga telah banyak dibuktikan tetapi mekanisme penyebabnya masih belum jelas. Hubungan yang terbalik antara O.felineus dengan respon terhadap alergen menunjukkan adanya keterlibatan sel $\mathrm{T}$ regulator pada infeksi cacing ini (Ogorodova et al., 2007). Adanya keterlibatan sel $\mathrm{T}$ regulator berhubungan dengan kecepatan pertumbuhan tumor dan buruknya prognosa suatu keganasan (Tong et al., 2017).

3. Malaria dan Limfoma Burkitt Walaupun malaria tidak

termasuk ke dalam kelompok karsinogen, endemic Limfoma Burkitt di daerah sub Sahara Afrika secara geografi berhubungan erat dengan holoendemisitas dari Plasmodium falciparum. Dari beberapa penelitian epidemiologi, eksperimental dan laopran kasus di klinik menunjukkan bahwa terdapat efek sinergis antara genetik host dengan infeksi seperti virus Epstein Barr, Plasmodium falciparum dan HIV dengan perkembangan penyakit Limfoma Burkitt (Molyneux et al., 2012). Koinfeksi dengan Plasmodium falciparum dan infeksi virus Epstein Barr merupakan faktor resiko utama penyakit Limfoma Burkitt endemik. Pada penelitian yang dilakukan di Malawi, diketahui bahwa pasien dengan Limfoma Burkitt endemik mempunyai prevalensi infeksi Plasmodium falciparum yang tinggi disertai dengan keragaman genetik Plasmodium falciparum yang tinggi jika dibandingkan dengan daerah non endemik (Johnston, 2014). Beberapa hipotesis mengenai mekanisme malaria menyebabkan peningkatan resiko kejadian Limfoma Burkitt adalah; 1) ekspansi populasi sel B yang terinfeksi virus Epstein Barr, 2) supresi sel $\mathrm{T}$ spesifik virus Epstein Barr, 3) Reaktivasi virus Epstein Barr dan terjadinya aktivasi yang diinduksi oleh cytidine deaminase (AID)-dependent genomic translocation (Tong et al., 2017).

4. Strongyloides stercoralis dan Keganasan

Strongyloidiasis adalah penyakit yang disebabkan oleh Strongyloides stercoralis. Penyakit ini dapat berlangsung silent maupun menimbulkan gejala yang ringan hingga berat. Gejala yang timbul dapat berupa terdapatnya lesi kulit dan gejala saluran cerna. Penelitian epidemiologi menunjukkan bahwa terdapat hubungan ko-infeksi Strongyloides stercoralis dan infeksi Human $T$ Lymphocyte Virus-1 (HTLV-1) dengan kejadian leukemia / limfoma (Tanaka et al., 2016). Infeksi S.stercoralis akan 
merangsang replikasi HTLV-1 dan menginduksi ekspansi poliklonal sel $\mathrm{T}$ yang terinfeksi HTLV-1 dengan pengaktivan sistem IL-2/IL-2R (Dehal et al., 2002).

Suatu laporan kasus di Korea mendapatkan bahwa seorang pasien yang terinfeksi cacing Strongylodes stercoralis mengalami adenokarsinoma gaster stadium awal. Penelitian lebih lanjut menunjukkan bahwa adenokarsinoma gaster dan jaringan adenoma tersebut disebabkan oleh S.stercoralis (Yang et al., 2015). Penelitian lain di Columbia juga mendapatkan adanya hubungan infeksi cacinmg ini dengan keganasan kolorektal (Brignole et al., 2015). Dari beberapa hasil penelitian ini dapat disimpulkan bahwa Strongyloides stercoralis tidak hanya sebagai kofaktor penginduksi leukemia / limfoma tetapi juga menginduksi adenokarsinoma kolorektal akibat interaksi respon imun host dengan cacing (Tong et al., 2017).

5. Tripanosomiasis dan Keganasan

Dari beberapa penelitian diketahui bahwa terdapat hubungan penyakit tripanosomiasis dengan timbulnya keganasan. Beberapa di antaranya dilaporkan; 1) chagasic megaesophagus dapat berkembang menjadi esophageal leiomyosarcoma,

2) penderita uterine leiomyoma mempunyai serologi positif Chagas Disease, 3) terdapat hubungan chagasic megacolon dengan keganasan kolorektal (Tong et al., 2017).

\section{B. Pembahasan}

Penelitian bidang parasitologi terakhir telah mengungkapkan bahwa infeksi parasite dapat memicu terjadinya perubahan ke arah penyakit keganasan. Di beberapa daerah endemik parasit tertentu, terdapat peningkatan jumlah kasus keganasan dengan pola yang sama. Penelitian masih terus berlanjut mengenai factor-faktor karsinogen pada suatu organisme parasit, onkogen dan faktor lainnya. Pada daerah endemis malaria, sangat diperlukan tindakan untuk mengendalikan kasus malaria kronis. Strongyloides stercoralis dapat memicu terjadinya suatu keganasan apabila terjadi interaksi dengan HTLV-1. Mekanisme induksi terjadinya keganasan ini tidak lepas dari proses stress oksidatif yang disebabkan oleh infeksi parasit.

\section{Kesimpulan}

Hubungan antara infeksi parasite dengan karsinogenesis telah banyak dibuktikan. Schistosoma haematobium, Opistorchis viverrini dan Chlonorchis sinensis mempunyai potensi karsinogeik yang lebih tinggi dibandingkan Opistorchis felineus dan Schistosoma. Terdapat tiga mekanisme karsinogenik parasit ini antara lain; inflamasi kronik, stress oksidatif metabolik yang diinduksi oleh infeksi parasit, kerusakan jaringan akibat parasit yang terjadi selama proses penyembuhan dan kompensasi tubuh. Bagaimanapun juga mekanisme pasti tentang hal ini masih belum jelas. Penelitian yang dilakukan selama ini lebih terfokus pada identifikasi karsinogen, signaling pathway, atau onkogen yang meningkatkan terbentuknya tumor. 


\section{BIBLIOGRAFI}

Bouvard, V., Baan, R., Straif, K., Grosse, Y., Secretan, B., El Ghissassi, F., Benbrahim-Tallaa, L., Guha, N., Freeman, C., \& Galichet, L. (2009). A Review Of Human Carcinogens--Part B: Biological Agents. The Lancet. Oncology, 10(4), 321-322.

Brignole, M., Investigators, S. U. P. 2 (Sup 2), Arabia, F., Investigators, S. U. P. 2 (Sup 2), Ammirati, F., Investigators, S. U. P. 2 (Sup 2), Tomaino, M., Investigators, S. U. P. 2 (Sup 2), Quartieri, F., \& Investigators, S. U. P. 2 (Sup 2). (2015). Standardized Algorithm For Cardiac Pacing In Older Patients Affected By Severe Unpredictable Reflex Syncope: 3-Year Insights From The Syncope Unit Project 2 (Sup 2) Study. Ep Europace, 18(9), 1427-1433.

Brindley, P. J., Da Costa, J. M. C., \& Sripa, B. (2015). Why Does Infection With Some Helminths Cause Cancer? Trends In Cancer, 1(3), 174-182.

Dehal, P., Satou, Y., Campbell, R. K., Chapman, J., Degnan, B., De Tomaso, A., Davidson, B., Di Gregorio, A., Gelpke, M., \& Goodstein, D. M. (2002). The Draft Genome Of Ciona Intestinalis: Insights Into Chordate And Vertebrate Origins. Science, 298(5601), 2157-2167.

Emilio García-Asencio, I., \& Carlos García-Gómez, J. (2007). Effects Of Temporal Variation Of The Seaweed Caulerpa Prolifera Cover On The Associated Crustacean Community. Marine Ecology, 28(2), 324-337.

Humans, I. W. G. On The E. Of C. R. To. (2012). Pharmaceuticals. Volume 100

A. A Review Of Human Carcinogens. Iarc Monographs On The Evaluation Of Carcinogenic Risks To Humans, 100(Pt A), 1 .
Johnston, J. D. (2014). Physiological Links Between Circadian Rhythms, Metabolism And Nutrition. Experimental Physiology, 99(9), 11331137.

Krementsov, D. N., Weng, J., Lambelé, M., Roy, N. H., \& Thali, M. (2009).

Tetraspanins Regulate Cell-To-Cell Transmission Of Hiv-1. Retrovirology, 6(1), 1-13.

Maeng, H. Y., Jang, H. Y., \& Li, J. M. (2016). A Critical Review Of The Motivational Factors For Festival Attendance Based On Meta-Analysis. Tourism Management Perspectives, 17, $16-25$.

Molyneux, E. M., Rochford, R., Griffin, B., Newton, R., Jackson, G., Menon, G., Harrison, C. J., Israels, T., \& Bailey, S. (2012). Burkitt's Lymphoma. The Lancet, 379(9822), 1234-1244.

Ogorodova, L. M., Freidin, M. B., Sazonov, A. E., Fedorova, O. S., Gerbek, I. E., Cherevko, N. A., \& Lebedeva, N. Y. (2007). A Pilot Screening Of Prevalence Of Atopic States And Opisthorchosis And Their Relationship In People Of Tomsk Oblast. Parasitology Research, 101(4), 1165-1168.

Organization, W. H. (2013). Global Tuberculosis Report 2013. World Health Organization.

Palmer, A. (2012). Introduction To Marketing: Theory And Practice. Oxford University Press.

Park, J., \& Park, M. (2016). Qualitative Versus Quantitative Research Methods: Discovery Or Justification? Journal Of Marketing Thought, 3(1), 1-8.

Petney, T. N., Andrews, R. H., Saijuntha, W., Wenz-Mücke, A., \& Sithithaworn, P. (2013). The Zoonotic, Fish-Borne Liver Flukes Clonorchis Sinensis, Opisthorchis Felineus And Opisthorchis Viverrini. International Journal For 
Parasitology, 43(12-13), 1031-1046.

Sithithaworn, P., Andrews, R. H., Van De, N., Wongsaroj, T., Sinuon, M., Odermatt, P., Nawa, Y., Liang, S., Brindley, P. J., \& Sripa, B. (2012). The Current Status Of Opisthorchiasis And Clonorchiasis In The Mekong Basin. Parasitology International, 61(1), 10-16.

Tanaka, S. C., Doya, K., Okada, G., Ueda, K., Okamoto, Y., \& Yamawaki, S. (2016). Prediction Of Immediate And Future Rewards Differentially Recruits CorticoBasal Ganglia Loops. In Behavioral Economics Of Preferences, Choices, And Happiness (Pp. 593-616). Springer.

Tong, T., Li, G., Liu, X., \& Gao, Q. (2017). Image Super-Resolution Using Dense Skip Connections. Proceedings of The Ieee International Conference On Computer Vision, 4799-4807.

Yang, W. S., Noh, J. H., Jeon, N. J., Kim, Y. C., Ryu, S., Seo, J., \& Seok, S. Il. (2015). High-Performance Photovoltaic Perovskite Layers Fabricated Through Intramolecular Exchange. Science, 348(6240), 1234-1237. 